\section{Fungal Ecology of Strawberry Flower Anthers and the Saprobic Role of Cladosporium cladosporioides in Relation to Fruit Deformity Problems}

\author{
Steven T. Koike ${ }^{1}$ \\ University of California Cooperative Extension, 1432 Abbott Street, Salinas, \\ CA 93901
}

\author{
Miguel S. Vilchez and Albert O. Paulus \\ Department of Plant Pathology, University of California, Riverside, \\ CA 92521
}

Additional index words. anthers, catfacing, Fragaria $\times$ ananassa, fungal ecology, pollination, Botrytis gray mold

\begin{abstract}
California has an extensive strawberry (Fragaria $\times$ ananassa L.) industry that has built its reputation on the production of large volumes of fruit that are evenly and fully developed. While some fruit deformity occurs every year, in various counties during the 1997-2000 seasons there were higher than usual numbers of uneven or "catfaced" strawberry fruit. It was thought that the presence of the fungus Cladosporium cladosporioides (Fresen.) G.A. De Vries on flower anthers may have interfered with pollination and increased cull rates. We collected and incubated flower anthers to determine the fungal populations on such tissue and found that $C$. cladosporioides accounted for the majority of the culturable fungal colonies present. However, while $100 \%$ of a flower's anthers were colonized with $C$. cladosporioides after spray inoculations, the incidence and severity of malformed fruit were not significantly different from untreated flowers. Physically removing all anthers shortly after anthesis likewise did not result in significant differences in fruit quality when compared to untreated control flowers. We conclude that C. cladosporioides colonization of flower anthers has a minimal impact on fruit quality under most field conditions.
\end{abstract}

California has an extensive strawberry industry that produces large yields of fruit. In 2000 the state grew 11,170 ha of strawberries and marketed 688,553 tons of fruit with a gross value of over $\$ 767$ million (California Dept. of Food and Agriculture, 2002). The strawberry "fruit" is composed of an aggregate of multiple ovaries and the underlying stem receptacle; formation of the fruit is the result of a complex series of events (Darrow, 1929, 1966; Havis, 1943; Nitsch, 1950; Valleau, 1918). At pollination, pollen from stamens fall on pistils that are embedded in the receptacle. The female ovules are fertilized and the resulting embryos develop into hard seeds called achenes. These single-ovule achenes, which are the true fruit of the strawberry, subsequently release auxin hormones that stimulate the surrounding receptacle tissue to enlarge and ripen. Excel-

Received for publication 15 Apr. 2002. Accepted for publication 28 Aug. 2002. We thank Adria C. Bordas, Neal De Vos, Todd Etchandy, Thom Flewell, Doug Gubler, Diana Henderson, A.G. Kawamura, Rod Koda, Kirk Larson, Ken Lewis, Cecil Martinez, Mark Murai, David Murray, Gary Omori, Trino Ramirez, Miguel Ramos, David and Elia Vasquez, Frank Westerlund, and Christopher Winterbottom for assistance with this project. We acknowledge the California Strawberry Commission for supporting this research. The first author thanks A.O. Paulus for help, support, and encouragement.

${ }^{1}$ To whom reprint requests should be addressed. E-mail address: stkoike@ucdavis.edu. lent quality, fully formed strawberry fruit occur only if pollination and achene development is complete and evenly distributed around the receptacle. Most strawberry blossoms of commercial cultivars are perfect (hermaphroditic) flowers and therefore self-fertilize. In addition, a flower's pistils can receive pollen from other flowers via gravity, the movement of wind, and the activity of pollinating insects such as bees, flies, and thrips (Connor and Martin, 1973; Nye and Anderson, 1974).

There are various types of irregular, misshapen and hence unmarketable fruit that are known variously as catfaced fruit, button berries, or nubbins. Such low quality fruit develop to some degree every year in all strawberry producing regions. However, during the 1997-2000 seasons, strawberry growers in the central (Monterey and Santa Cruz counties) and southern (Orange and Ventura counties) coastal production areas of California experienced significant marketable yield loss due to catfaced fruit. During these same years researchers and growers observed extensive fungal growth of Cladosporium cladosporioides on strawberry flowers, as shown in Fig. 1A, and researchers explored the possibility that such colonization might interfere with pollination and result in malformed fruit. In greenhouse and laboratory experiments, this fungus was associated with a flower disease that could cause fruit deformities (Gubler et al., 1999a, 1999b). Strawberry growers therefore began to seek out fungicide treatments to control this fungus.

Species of Cladosporium are some of the most ubiquitous fungi in agricultural and other environments. These fungi are opportunistic colonizers of diverse substrates and are widely distributed because of the profuse, small, easily dispersed conidia that they produce. C. cladosporioides and C. herbarum (Pers.: Fr.) Link are the most commonly encountered species and are frequent colonizers of dead organic matter and senescing plant tissues, and are readily recovered from soil (Domsch et al., 1993). However, these two species are generally considered to be saprobic fungi or, less frequently, weak plant pathogens (Farr et al., 1989).

We conducted field surveys in 1998 to determine the incidence of $C$. cladosporioides on strawberry flowers and the amount of subsequently deformed fruit 3 weeks later. In the field we found that the fungus grew primarily on the anthers. We encountered associations that contradicted previous reports in that a field having a relatively high degree $(80 \%)$ of Cladosporium-infested anthers had a very low percentage of misshapen fruits. Another field had relatively low Cladosporium infestation levels (28\%) but significant yield losses due to deformed fruit (Table 1). Our objectives were to identify the fungal flora found on strawberry anthers in the field and to clarify the potential role of $C$. cladosporioides in causing deformed strawberry fruit under commercial field conditions.

\section{Materials and Methods}

Fungal flora on anthers. To evaluate the nature of the fungal flora on strawberry anthers, in 1999 we collected postanthesis secondary flowers from commercial fields of 'Camarosa' in the major California strawberry production areas of Orange and Ventura counties. All collected flowers were free from visible damage and contained stamens with completely yellow anthers. The first flower collection was made on 16 Feb. from seven different fields (Orange 1 to 5, Ventura 1 and 2). For each of these seven flower samples, we used sterilized jeweler's forceps to remove four randomly selected stamens from each of 20 flowers; these 80 stamens were placed directly into $100-\mathrm{mm}$ - diameter petri plates (10 stamens per plate) containing $2 \%$ water agar (Bacto Agar; Difco Co., Detroit) that had been acidified $(2.0 \mathrm{~mL}$ of $85 \%$ lactic acid/1000 mL). The filament base was positioned into the agar so that the anther remained above, but did not touch, the agar surface. From the same 20 flowers another four randomly selected stamens were removed and surface disinfested by soaking the stamens in a $1.5 \%$ bleach plus Tween $20(30 \mu \mathrm{L} / 100 \mathrm{~mL})$ solution for $1 \mathrm{~min}$. The stamens were then rinsed three times in sterile distilled water, allowed to drain for $1 \mathrm{~min}$ on sterile paper towels, then placed upright in the acidified water agar. Plates were incubated under fluorescent lights at $24^{\circ} \mathrm{C}$ for 1 week, then all anthers were examined for the presence of fungal growth. The percent colonization by each fungal species was calculated, 
and representative isolates were examined and identified using a compound microscope. An analysis of variance (ANOVA) test was used (Statgraphics Plus 5.0; Statistical Graphics Corp., Englewood Cliffs, N.J.) to determine if statistically significant differences were present for $C$. cladosporioides and Botrytis cinerea Pers.: Fr. recovery from disinfested and nondisinfested treatments.

The stamen incubation experiment was repeated on 19 Apr. and flowers were collected in the same manner from nine different fields (Orange 1 to 5, Ventura 1 to 4). Based on the results from the first collection, we plated 80 stamens per sample without using the surface disinfest treatment.

Field inoculations, simulation of anther damage. In 1999, we initiated a study to evaluate the effects of anther damage and $C$. cladosporioides colonization on possible fruit deformity problems. Over the 3-year span of these experiments, replicated trials were established in commercial fields in three of the major strawberry producing regions of California (Monterey, Orange, and Ventura counties). Strawberry cultivars in the trials were the following: all Orange and Ventura county plants were 'Camarosa'; 1999 Monterey County plants were 'Selva'; 2001 Monterey County plants were 'Diamante'. Each of the four replicated plots in Orange and Ventura counties was one bed wide ( $=163 \mathrm{~cm}$, four rows of plants per bed) and $31 \mathrm{~m}$ long; the Monterey County plots were two beds wide (122 $\mathrm{cm}, 2$ rows of plants per bed) and $31 \mathrm{~m}$ long. Within each plot, 20 partially or newly opened secondary flowers were randomly selected and marked for each of the four treatments. These flowers were carefully selected so that we were certain the anthers had not yet dehisced. Treatments were the following: untreated control; all anthers removed by using jeweler's forceps, as shown in Fig. 1B; inoculation by misting a spore suspension of $C$. cladosporioides onto the flowers; water control in which sterile distilled water was misted onto the flowers. All C. cladosporioides isolates (98-01 to 98-04 and 99-05) used in the study were originally recovered from strawberry anthers. The $C$. cladosporioides inoculum was prepared by growing the five isolates on potato dextrose agar (Difco Co.) for 3 weeks, dislodging the conidia by washing the agar surface with sterile distilled water, straining the mixture through two layers of cheese cloth, and combining the resulting five mixtures. Final concentration of the inoculum was $1 \times 10^{8}$ conidia $/ \mathrm{mL}$. Based on results from the 1999 and 2000 field trials, the water control treatment was omitted for the 2001 trials.

Two experimental sites were established in 1999 (both in Monterey County), four in 2000 (sites 1 and 2 in Orange County, sites 3 and 4 in Ventura County), and five in 2001 (sites 1 and 2 in Orange County, sites 3 and 4 in Ventura County, site 5 in Monterey County). All plots were irrigated, sprayed for pests and diseases, and managed as per commercial practice. Typical fungicide programs in these commercial fields consisted of captan, thiram, or fenhexamid sprays for Botrytis gray mold
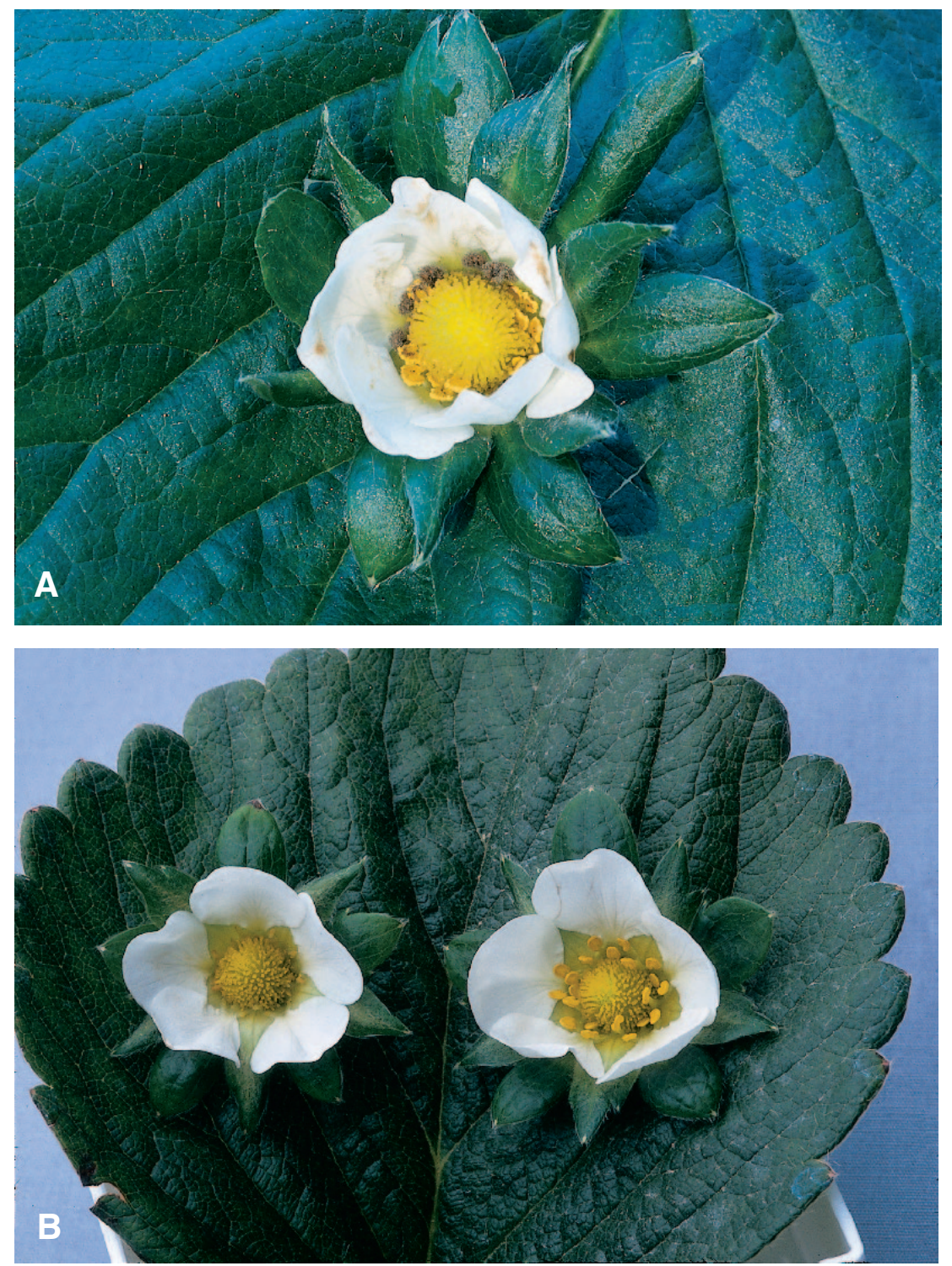

Fig. 1. Strawberry flowers from commercial fields. (A) Strawberry flower showing anthers naturally colonized by Cladosporium cladosporioides. (B) Strawberry flowers showing untreated (right) and anther removal (left) treatments used in field experiments.

(caused by $B$. cinerea) applied at 8 - to $14-\mathrm{d}$ intervals, and myclobutanil or sulfur sprays for powdery mildew [caused by Sphaerotheca macularis (Wall.:Fr.) Lind] applied at 10- to 14-d intervals. About 3 weeks after treatment, the fruit that developed from the marked flowers were collected and evaluated for fruit deformities. Collections were scheduled so that the fruit would be enlarged and almost harvest size but not yet red in color, to prevent possible removal by harvesters. The percent of fruit having any deformities or irregularities was calculated for each set. A severity ranking was also assigned to each fruit using the following scale: 1 = no defects or deformities; 2 = only the fruit tip is underdeveloped or crooked; 3 $=$ lateral deformities or creases are present; 4 $=$ severe fruit deformities and irregularities. An ANOVA test was used on the percent and severity data (Statgraphics Plus 5.0) to determine if statistically significant differences were present between the treatments.

\section{Results}

Fungal flora on anthers. There were no statistically significant differences $(P \leq 0.05)$ between colonization percentages of disinfested vs. nondisinfested treatments for either C. cladosporioides $(P=0.54)$ or $B$. cinerea $(P$ $=0.08)$. Therefore, the surface disinfest step was omitted for the second experiment.

The three sets of stamen incubations resulted in similar findings (Table 2). Cladosporium fungi extensively colonized the anther tissue. Of the 23 sets of stamens, only four samples had colonization percentages of $\approx 10 \%$ or less (16 Feb.: Ventura 2, not disinfested; Ventura 1, disinfested; 19 Apr.: Ventura 2 and 4). All other samples had significantly higher Cladosporium colonization percentages, often exceeding $80 \%$. Representative isolates had ellipsoidal to lemon-shaped conidia that were mostly smooth walled and rarely exceeded 6 $\mu \mathrm{m}$ in length. Conidia were single celled 
and olivaceous brown. These isolates were identified as C. cladosporioides (Domsch et al., 1993). We observed that stamens mostly supported C. cladosporioides growth only on the anther tissue, which became brown and necrotic after 1 week. However, the filament tissue rarely turned necrotic and did not support C. cladosporioides sporulation.

With one exception (16 Feb.: Ventura 1 disinfested), all stamen sets had $B$. cinerea colonization percentages of well below $10 \%$. Most of the stamens had no B. cinerea growth at all (Table 2). In contrast to $C$. cladosporioides, when $B$. cinerea was present on the anther, the fungus continued to grow down into the filament tissue, causing browning and necrosis of the filament and sporulation on that tissue.

Other fungi were observed occasionally on the anthers. Colonies of Alternaria alternata (Fr.: Fr.) Keissl. and a monoverticillate Penicillium Link: Fr. species were observed on a few anthers. As with the $C$. cladosporioides colonization, the Alternaria and Penicillium growth was restricted to the anther and did not progress down into the filament.

Field inoculations, simulation of anther damage. One week after inoculation, the high conidial concentration of $C$. cladosporioides inoculum resulted in $100 \%$ colonization of the treated anthers. Fruit deformity percentages were generally consistent between the nine sites (Table 3). With one exception (2001, site 1$)$, no significant differences $(P \leq 0.05)$ were observed between control treatments, anther removal, or inoculation with C. cladosporioides, as shown in Fig. 2. For site 1 in 2001 , the untreated control had a significantly higher percentage of deformed fruit $(38.7 \%)$ than the $C$. cladosporioides inoculation $(19.5 \%)$. Overall fruit deformity percentages were higher in year 2001 compared with the previous two years.

Fruit deformity severity ratings were also consistent over the nine sites and three years of the experiment (Table 3). Generally, no significant differences $(P \leq 0.05)$ were found between the untreated, anther removal, and C. cladosporioides inoculation treatments as shown in Fig. 2. At one site (2001, site 1) the untreated control had a higher severity rating than both anther removal and C. cladosporioides inoculated treatments. Growers who were shown harvested fruit from all of the treatments did not discern significant differences in fruit quality from the various treatment sets.

\section{Discussion}

Our field surveys demonstrated that $C$. cladosporioides is a significant component of the fungal flora of strawberry flowers produced in commercial fields in California. This is not surprising because $C$. cladosporioides is one of the most commonly encountered fungi in agricultural environments and is an excellent colonizer of many organic substrates. Anthers and pollen are rich sources of nutrients and would provide a ready substrate for saprobes such as C. cladosporioides. Our field observations, recorded over a three year period, indicate that $C$. cladosporioides rarely sporulates on the

Table 1. Survey of Cladosporium cladosporioides-infested strawberry flowers and associated fruit deformity losses in selected fields in 1998.

\begin{tabular}{lcc}
\hline $\begin{array}{l}\text { Field no. } \\
\text { (county) }\end{array}$ & $\begin{array}{c}\text { Mean \% of anthers } \\
\text { infested by } \\
\text { C. } \text { cladosporioides }^{z}\end{array}$ & $\begin{array}{c}\text { \% of fruit } \\
\text { showing } \\
\text { deformities }^{y}\end{array}$ \\
\hline 1 (Orange) & 80 & 28 \\
2 (Monterey) & 58 & 35 \\
3 (Santa Cruz) & 28 & 67 \\
\hline
\end{tabular}

${ }^{2}$ Four evaluation areas ( 1 bed $\times 16 \mathrm{~m}$ each) were marked in each field. Fifty flowers in each area were selected, tagged, and evaluated for the presence or absence of $C$. cladosporioides growth.

${ }^{y}$ After $24 \mathrm{~d}$, the fruit that had developed from the tagged flowers were evaluated for presence or absence of any fruit deformity or irregular shape.

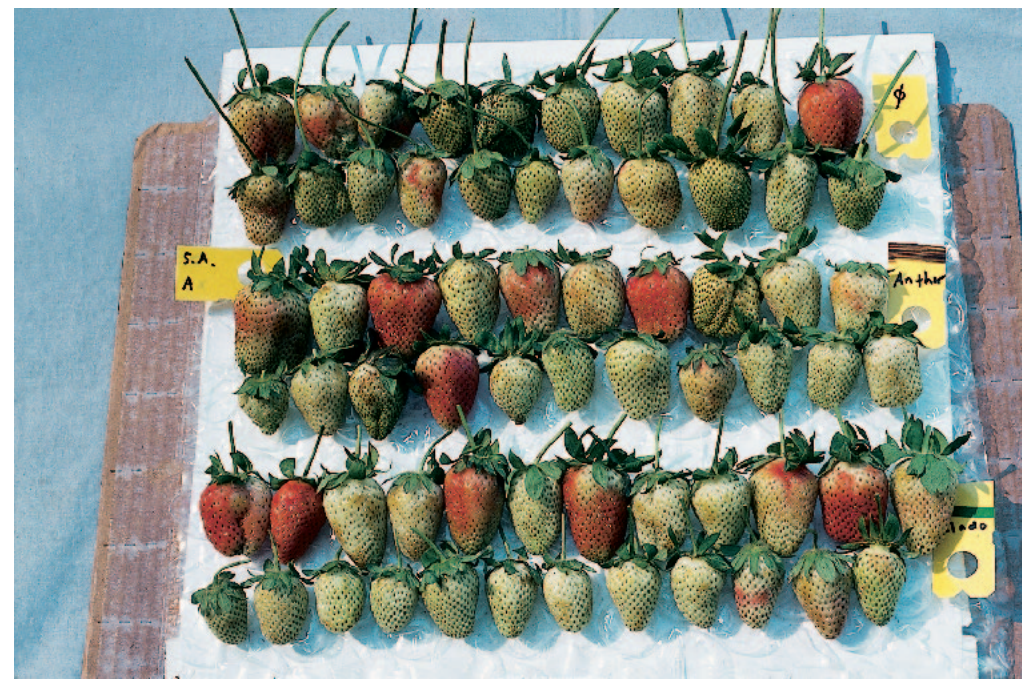

Fig. 2. Fruit harvested from field trials. Treatments were the following: untreated control (top two rows), anther removal (middle two rows), inoculation with Cladosporium cladosporioides (bottom two rows).

anthers of newly opened flowers. In contrast, C.cladosporioides is very commonly observed on older flowers in which the anthers have dehisced and petals and other flower organs begin to show signs of damage and senescence. The tendency for $C$. cladosporioides to colonize the anther and to not grow on or cause necrosis on the filament adds additional evidence that this fungus is nonpathogenic to strawberry flowers.

Our anther surveys and incubations demonstrated that $B$. cinerea was infrequently found on these flower parts. Field observations likewise indicated that $B$. cinerea was much less evident on anther tissue than C. cladosporioides. These findings were consistent with the isolations made from undamaged strawberry flowers in Oregon (Powelson, 1960) and the U. K. (Jarvis, 1962), which also yielded low percentages of $B$. cinerea from stamens. $B$. cinerea is considered one of the most important primary pathogens of strawberries worldwide and can cause both blossom blight and fruit rot diseases. Under cool, wet conditions $B$. cinerea can infect petals, stamens, and pistils and cause necrosis and death of the flower (Bulger et al., 1987). This pathogen can also rapidly grow down the filament and infect the young, developing receptacle, resulting in latent infections in which the mycelium becomes quiescent.
When the fruit ripens, the fungus can become active and cause the fruit rot known as gray mold (Bristow et al., 1986).

It is interesting to postulate that C. cladosporioides occupies an ecological niche on flower anthers that contributes to the exclusion of $B$. cinerea from these tissues. $B$. cinerea is clearly able to infect anther tissues (Bristow et al., 1986) and strawberry pollen stimulates the germination of $B$. cinerea conidia (Borecka and Millikan, 1973; Chou and Preece, 1968). However, if extensive C. cladosporioides colonization takes place prior to the deposition of $B$. cinerea conidia, then anther and pollen resources could be monopolized by this saprobic fungus. Chou and Preece (1968) and Powelson (1960) demonstrated that if anthers and other flower parts were physically removed from fruit at various stages of maturity, fruit rot caused by $B$. cinerea was reduced in every instance. Ecologically, C. cladosporioides growth on anthers can likewise "remove" anthers from colonization opportunities for B. cinerea, a hypothesis put forth by Bhatt and Vaughan (1962, 1963) regarding $C$. herbarum on strawberry flowers in Oregon. This exclusion may benefit the strawberry grower in that with reduced access to anther and pollen nutrients, $B$. cinerea colonization of flower parts is lessened and blossom blight and fruit rot diseases are less 
Table 2. Fungal species colonizing anthers of strawberry flowers collected from commercial fields in 1999.

\begin{tabular}{|c|c|c|c|c|c|c|c|c|}
\hline \multirow[b]{3}{*}{ Field no. } & \multicolumn{8}{|c|}{ Mean $\%$ of anthers colonized by fungal species } \\
\hline & \multicolumn{4}{|c|}{ Not surface disinfested } & \multicolumn{4}{|c|}{$\begin{array}{ll}\text { Surface disinfested } \\
\end{array}$} \\
\hline & $\begin{array}{l}\text { Cladosporium } \\
\text { cladosporioides }\end{array}$ & $\begin{array}{l}\text { Botrytis } \\
\text { cinerea }\end{array}$ & $\begin{array}{c}\text { Alternaria } \\
\text { alternata }\end{array}$ & $\begin{array}{l}\text { Penicillium } \\
\text { species }\end{array}$ & $\begin{array}{l}\text { Cladosporium } \\
\text { cladosporioides }\end{array}$ & $\begin{array}{l}\text { Botrytis } \\
\text { cinerea }\end{array}$ & $\begin{array}{c}\text { Alternaria } \\
\text { alternata }\end{array}$ & $\begin{array}{l}\text { Penicillium } \\
\text { species }\end{array}$ \\
\hline & \multicolumn{8}{|c|}{ Sample date $-16 \mathrm{Feb} \mathrm{z}^{\mathrm{z}}$} \\
\hline Orange 1 & 45 & 0 & 0 & 1 & 45 & 3 & 1 & 0 \\
\hline Orange 2 & 80 & 0 & 0 & 0 & 85 & 0 & 0 & 0 \\
\hline Orange 3 & 90 & 0 & 1 & 0 & 88 & 0 & 0 & 0 \\
\hline Orange 4 & 38 & 0 & 0 & 0 & 48 & 5 & 0 & 0 \\
\hline Orange 5 & 53 & 0 & 1 & 0 & 68 & 0 & 0 & 0 \\
\hline Ventura 1 & 33 & 5 & 0 & 0 & 11 & 17 & 0 & 0 \\
\hline \multirow[t]{2}{*}{ Ventura 2} & 8 & 0 & 0 & 0 & 25 & 0 & 0 & 0 \\
\hline & \multicolumn{8}{|c|}{ Sample date-19 Apr.y } \\
\hline Orange 1 & 66 & 0 & 0 & 0 & & & & \\
\hline Orange 2 & 67 & 0 & 0 & 0 & & & & \\
\hline Orange 3 & 91 & 0 & 1 & 0 & & & & \\
\hline Orange 4 & 88 & 0 & 0 & 2 & & & & \\
\hline Orange 5 & 69 & 0 & 0 & 0 & & & & \\
\hline Ventura 1 & 48 & 0 & 1 & 0 & & & & \\
\hline Ventura 2 & 11 & 1 & 0 & 0 & & & & \\
\hline Ventura 3 & 30 & 0 & 0 & 1 & & & & \\
\hline Ventura 4 & 0.5 & 0 & 0 & 0 & & & & \\
\hline
\end{tabular}

Table 3. Percent and severity of strawberry fruit deformity following various flower treatments in field experiments.

\begin{tabular}{|c|c|c|c|c|c|c|c|c|c|c|c|}
\hline \multirow[b]{3}{*}{ Treatments } & \multicolumn{11}{|c|}{$\%$ Fruit deformities } \\
\hline & \multicolumn{2}{|c|}{1999} & \multicolumn{4}{|c|}{2000} & \multicolumn{5}{|c|}{2001} \\
\hline & $\overline{\text { Site } 1^{z}}$ & $\overline{\text { Site } 2}$ & Site 1 & Site 2 & Site 3 & Site 4 & Site 1 & Site 2 & Site 3 & Site 4 & Site 5 \\
\hline Untreated control & 0.5 & 1.0 & 3.0 & 1.0 & 3.0 & 6.0 & 38.7 & 9.7 & 26.3 & 27.0 & 9.9 \\
\hline Anther removal & 1.0 & 0.8 & 3.0 & 3.0 & 6.0 & 3.8 & 30.0 & 15.9 & 14.6 & 27.2 & 9.4 \\
\hline Cladosporium inoculation & 0.3 & 0.3 & 0.8 & 1.0 & 3.0 & 6.0 & 19.5 & 11.5 & 21.0 & 22.5 & 10.2 \\
\hline Water control & 0.5 & 0.5 & 3.0 & 1.3 & 6.0 & 6.0 & --- & --- & --- & --- & --- \\
\hline \multirow[t]{2}{*}{$\operatorname{LSD}(P=0.05)$} & NS & NS & NS & NS & NS & NS & $11.9^{*}$ & NS & NS & NS & NS \\
\hline & \multicolumn{11}{|c|}{ Fruit deformity severity } \\
\hline Untreated control & 1.1 & 1.2 & 1.8 & 2.0 & 1.5 & 1.4 & 1.8 & 1.1 & 1.5 & 1.4 & 1.3 \\
\hline Anther removal & 1.1 & 1.1 & 1.8 & 1.8 & 1.4 & 1.4 & 1.5 & 1.2 & 1.2 & 1.4 & 1.2 \\
\hline Cladosporium inoculation & 1.1 & 1.1 & 1.5 & 1.7 & 1.5 & 1.3 & 1.4 & 1.2 & 1.4 & 1.4 & 1.2 \\
\hline Water control & 1.1 & 1.1 & 1.7 & 1.9 & 1.3 & 1.5 & --- & --- & --- & --- & --- \\
\hline $\operatorname{LSD}(P=0.05)$ & NS & NS & NS & NS & NS & NS & $0.2^{*}$ & NS & NS & NS & NS \\
\hline
\end{tabular}

${ }^{2}$ Site locations: 1999: both in Monterey County); 2000: sites 1 and 2 in Orange County, sites 3 and 4 in Ventura County; 2001: sites 1 and 2 in Orange County, sites 3 and 4 in Ventura County, site 5 in Monterey County.

Ns, "Nonsignificant or significant at $P=0.05$, respectively.

severe than they might be otherwise.

Our 3-year, replicated study was completed in 11 fields in three counties and included three strawberry cultivars. All our data failed to indicate that $C$. cladosporioides could cause significant fruit deformity losses under field conditions. Extremely high inoculum levels and colonization of $100 \%$ of a flower's anthers did not result in higher percentages or severity of fruit deformity when compared to untreated flowers. The development of a blossom blight disease and subsequent misshapen fruit in laboratory and greenhouse experiments (Gubler et al., 1999a, 1999b) indicates that perhaps under some environmental conditions $C$. cladosporioides could impact fruit quality. However, laboratory and greenhouse conditions would not reproduce the complex environmental and pollination conditions present in commercial production fields. In some cases, the greenhouse environment actually results in an increase of strawberry fruit deformities as pointed out by Way (1968). The impact of a suspected pathogen on strawberry pollination and fruit development in the field would therefore best be evaluated under field conditions.

The anther removal treatment was designed to simulate a situation in which Cladosporium or any other potential pathogen caused significant loss of a particular flower's own pollen source. This treatment demonstrated the remarkable ability of the strawberry flower to draw upon sources of pollen that are external to its own stamens. Even if a fungus succeeded in interfering with pollen release, sufficient pollen is available through pollinator activity to substitute for the loss of a flower's own anthers. The long period of pistil receptivity, up to $5 \mathrm{~d}$ after anthesis according to Moore (1964), further enables a flower to benefit from pollen dispersal in a field.

Strawberry pollination and receptacle development is a complex process and many factors can interfere and cause uneven, misshapen fruit. Insects such as lygus bugs (Lygus Hesperus Knight) can feed on the achenes and cause such deformities (Allen and Gaede, 1963;
Schaefers, 1966). Some strawberry cultivars show inherent tendencies to pollinate less efficiently and hence rely more heavily on pollinating insects (Bagnara and Vincent, 1988; Chagnon et al., 1989; Free, 1968; Moore, 1969). Flowers can produce sterile pistils which can never be pollinated (Darrow, 1927). Blossom position is important in that primary fruit usually have a higher percentage of normally developing achenes while tertiary fruit have a lower percentage (Janick and Eggert, 1968). Low or high temperature extremes can damage flower organs, interfere with pollen formation, and reduce pollen viability. Some environmental conditions can influence the amount and rate of pollen release and distribution (Kronenberg, 1959; Kronenberg et al., 1959). Boron deficiency can interfere with the pollination process and result in malformed fruit (Ulrich et al., 1980). Even cultural practices, such as the application of fungicides and other chemicals, can inhibit pollen germination and result in deformed fruit (Eaton and Chen, 1969a, 1969b; Khanizadeh and Buszard, 1987). Therefore, it 


\section{Plant Pathology}

is clear that many factors other than colonization by $C$. cladosporioides could account for increases in misshapen, unmarketable fruit as periodically experienced by commercial growers in California.

In summary, C. cladosporioides is a prominent component of the strawberry flower fungal ecology and is commonly observed on the anthers. In contrast, the strawberry pathogen $B$. cinerea was rarely found on such tissue. While $C$. cladosporioides is often associated with anthers, it appears that this fungus is not a pathogen of strawberry flowers under most field conditions. Therefore, application of fungicides for the purpose of preventing C.cladosporioides growth appears to be unwarranted and would be a needless addition of chemicals to the environment. Significant harvest losses due to misshapen fruit are most likely attributable to a number of other causes.

\section{Literature Cited}

Allen, W.W. and S.E. Gaede. 1963. The relationship of lygus bugs and thrips to fruit deformity in strawberries. J. Econ. Entomol. 56:823-825.

Bagnara, D. and C. Vincent. 1988. The role of insect pollination and plant genotype in strawberry fruit set and fertility. J. Hort. Sci. 63:69-75.

Bhatt, D.D. and E.K. Vaughan. 1962. Preliminary investigation on biological control of gray mold (Botrytis cinerea) of strawberries. Plant Dis. Rptr. 46:342-345.

Bhatt, D.D. and E.K. Vaughan. 1963. Inter-relationships among fungi associated with strawberries in Oregon. Phytopathology 53:217-220.

Borecka, H. and D.F. Millikan. 1973. Stimulatory effect of pollen and pistillate parts of some horticultural species upon the germination of Botrytis cinerea spores. Phytopathology 63: 1431-1432.

Bristow, P.R., R.J. McNicol, and B. Williamson. 1986. Infection of strawberry flowers by Botrytis cinerea and its relevance to grey mould development. Ann. Appl. Biol. 109:545-554.

Bulger, M.A., M.A. Ellis, and L.V. Madden. 1987.
Influence of temperature and wetness duration on infection of strawberry flowers by Botrytis cinerea and disease incidence of fruit originating from infected flowers. Phytopathology 77 : $1225-1230$.

California Department of Food and Agriculture. 2002. California agricultural resource directory. Website: www.cdfa.ca.gov/card.htm. 20 Feb. 2002.

Chagnon, M., J. Gingras, and D. de Oliveira. 1989. Effect of honey bee (Hymenoptera: Apidae) visits on the pollination rate of strawberry. J. Econ. Entomol. 82:1350-1353.

Chou, M.C. and T.F. Preece. 1968. The effect of pollen grains on infections caused by Botrytis cinerea. Ann. Appl. Biol. 62:11-22.

Connor, L.J. and E.C. Martin. 1973. Components of pollination of commercial strawberries in Michigan. HortScience 8:304-306.

Darrow, G.M. 1927. Sterility and fertility in the strawberry. J. Agr. Res. 34:393-411.

Darrow, G.M. 1929. Inflorescence types of strawberry varieties. Amer. J. Bot. 16:571-585.

Darrow, G.M. 1966. The strawberry: History, breeding, and physiology. Holt, Rinehart and Winston, New York.

Domsch, K.H., W. Gams, and T.-H.Anderson. 1993. Compendium of soil fungi. Vol. I. IHW-Verlag, Regensburg, Germany.

Eaton, G.W. and L.I. Chen. 1969a. The effect of captan on strawberry pollen germination. J. Amer. Soc. Hort. Sci. 94:558-560.

Eaton, G.W. and L.I. Chen. 1969b. Strawberry achene set and berry development as affected by captan sprays. J. Amer. Soc. Hort. Sci. 94:565-568.

Farr, D.F., G.F. Bills, G.P. Chamuris, and A.Y. Rossman. 1989. Fungi on plants and plant products in the United States. Amer. Phytopathol. Soc. Press, St. Paul, Minn.

Free, J. B. 1968. The pollination of strawberries by honey bees. J. Hort. Sci. 43:107-111.

Gubler, W.D., A.J. Feliciano, A.C. Bordas, E.C. Civerolo, J.A. Melvin, and N.C. Welch. 1999a. First report of blossom blight of strawberry caused by Xanthomonas fragariae and Cladosporium cladosporioides in California. Plant Dis. 83:400.

Gubler, W.D., C.J. Feliciano, A.C. Bordas, E.L. Civerolo, J.A. Melvin, and N.C. Welch. 1999b.
$X$. fragariae and C. cladosporioides cause strawberry blossom blight. California Agr. 53(4):26-28.

Havis, A.L. 1943. A developmental analysis of the strawberry fruit. Amer. J. Bot. 30:311-314.

Janick, J. and D.A. Eggert. 1968. Factors affecting fruit size in the strawberry. Proc. Amer. Soc. Hort. Sci. 93:311-316.

Jarvis, W.R. 1962. The infection of strawberry and raspberry fruits by Botrytis cinerea. Ann. Appl. Biol. 50:569-575.

Khanizadeh, S. and D. Buszard. 1987. Effects of the fungicides captan and Easout on strawberry fruit development. Adv. Strawberry Prod. 6:27-31.

Kronenberg, H.G. 1959. Poor fruit setting in strawberries: I. Causes of a poor fruit set in strawberries in general. Euphytica 8:47-57.

Kronenberg, H.G., J.P. Braak, and A.E. Zeilinga. 1959. Poor fruit setting in strawberries: II. Malformed fruits in Jucunda. Euphytica 8: 245-251.

Moore, J.N. 1964. Duration of receptivity to pollination of flowers of the highbush blueberry and the cultivated strawberry. Proc. Amer. Soc. Hort. Sci. 85:295-301.

Moore, J.N. 1969. Insect pollination of strawberries. J. Amer. Soc. Hort. Sci. 94:362-364.

Nitsch, J.P. 1950. Growth and morphogenesis of the strawberry as related to auxin. Amer. J. Bot. 37:211-215.

Nye, W.P. and J.L. Anderson. 1974. Insect pollinators frequenting strawberry blossoms and the effect of honey bees on yield and fruit quality. J. Amer. Soc. Hort. Sci. 99:40-44.

Powelson, R.L. 1960. Initiation of strawberry fruit rot caused by Botrytis cinerea. Phytopathology 50:491-494.

Schaefers, G.A. 1966. The reduction of insect-caused apical seediness in strawberries. J. Econ. Entomol. 59:698-706.

Ulrich, A., M.A.E. Mostafa, and W.W. Allen. 1980. Strawberry deficiency symptoms: A visual and plant analysis guide to fertilization. Bulletin 1917. Div. of Agr. and Natural Res. Univ. of California.

Valleau, W.D. 1918. Sterility in the strawberry. J. Agr. Res. 12:613-670.

Way, D.W. 1968. Strawberry fruit malformation: I. Pomological aspects. Annu. Rpt. E. Malling Res. Sta. 1967. 